\title{
Research on the Art Design College's Computer Network Entrepreneurship Plat From
}

\author{
Wang Ming ${ }^{1, a}$, ShanTan ${ }^{2, b}$ \\ ${ }^{1}$ College of Furniture and Art Design, Central south university of forestry and technology, ChangSha \\ Hunan, P.R.China \\ ${ }^{2}$ Art design departments of ZengCheng School, South China Normal University, Guangzhou \\ Guangdong, P.R.China \\ awangming68610@163.com, b24794065@qq.com
}

Keywords: Students; network business platform; art and design; innovative education

\begin{abstract}
At present, in the artistic design education in Colleges of China appeared in the realm of" enterprise education" as the core content of the reform, obtained better result also gained experience. But there are also problems. Based on the innovative education of art design and professional characteristics analysis, proves the reality and necessity of the university construction of art design professional business platform for the network (hereinafter referred to as the "business platform for the network." ), the effectiveness in the promotion of university art design education, and it improve students' innovation ability. And the actual operation of the platform design to provide a preliminary exploration. In 2011 April Academic Degrees Committee of the State Council, the Ministry of education to add "art" for the thirteenth disciplines, design upgrades for the first grade discipline. New courses to adapt to the development of China's economic, social, science and technology and higher education, also indicated that the promote of art and design disciplines' academic status. Focus on scientific and technological advances in today's world, the horizon of knowledge economy, national competitiveness and education in the comprehensive national strength in the important role of art and design college design education is the most fundamental task is to nurture students to become innovative, professional skills intensive, with good employment entrepreneurship modern design professionals.
\end{abstract}

The current situation of Chinese enterprise education for college students and the Business status.

UNESCO published in 1999, higher education in the 21st century: vision and action for the World Declaration, proposed the entrepreneurial skills and entrepreneurial spirit must be used as the basic goals of higher education; On deepening the education reform in China, promoting quality education decision also emphasizes: "stressing the cultivation of innovation ability of college students in higher education, practice skills and entrepreneurial spirit, a general increase in the humanistic quality of college students and science literacy." [1] In the field of higher education in China "career education" as the core content of boom, student venture employability is undoubtedly has become an important standard in evaluation of school success. Current internal practices in entrepreneurship education in universities and achieved certain results at the same time, still appeared the following questions:

1 the prevalence of entrepreneurship education of students work under the category of misunderstanding. Lack of link between teaching and practice of enterprise education;

2. Lack of clear entrepreneurial goal of entrepreneurship education guide and complete cultivation plan, diversity of student individuality development have not been fully discovered, lack of professionalism, Omni-directional guidance left majority. University student's pioneering work with no capital, no existing site, 3 without the experience of the common problems, only a few of the students will be able to realize the establishment and organization for market entity gleam of project; 
3. Entrepreneurship class too passive and routine. Heavy theory of light practice; Heavy short-term subject conclusion, light up long-term projects; Heavy personal behavior, light the team; many copy foreign mode, ignored China's situation and the universities, the market situation.

4. Lack of entrepreneurial scheme for the correct practice test evaluation system. College design education internal often only to be content as evaluation standard, neglecting social meaning and practical value, cause some practical innovation design only stays in the design on the drawing board, hard into productivity.

5. Off many of the resources advantage didn't get the integration and reflect lack of social linkage. Universities can provide the opportunity and practice are limited to meet the students entrepreneurship practice needs, students need to equal participation opportunity of business, but the internal lack of public resources sharing platform. Especially for the innovation of the life of professional design, need more close to the actual combat training platform of the market.

According to the survey, about $60 \%$ of the art design professional students tend to start their own businesses. But because the university student's pioneering work widespread "3 without" problem, only a few students can design company, founded entity studio, undertake market project. Finally to withstand test market and obtain the stable development is even less. [2] In general, there is a general lack of awareness of college students, entrepreneurship ability lacking, own pioneering atmosphere is far still did not form. At the same time university student's poineering work need adjust entrepreneurial mindset, establishing market view. And the lack of professional guidance, not a long-term stable development is the key problem affecting the university students' business. In the market rapidly changing today, college students' learning in school during practice becomes more and more important, need to colleges can build a wide coverage, long-term stability of the marketization of business practice platform.

\section{Network poineering advantage and disadvantage analysis}

Today, the network economy has increasingly become the core of the new economy. By the end of June, 2011, the number of users has reached 485 million, the network shopping users and more than 130 million. Starting a business network to become a reality of employment of the new choice. Starting a business network with "initial capital investment, low operating cost is low, the small risk, market range, flexible and profits high return time" and so on characteristics and advantages, so most of the independent business student chose through the network platform venture as the first choice of the first business.

Most art design professional students first venture third party market network platform to start a business. Although the third party venture platform operation marketization, coverage, trading convenience, low cost, for art design professional students in business, also have platform environment, lack of mixed and disorderly support and guidance, trading owe safety improvement, intellectual property is easy to attack, design evaluation and pricing standard chaos, businesses identical and professional characteristics and market combined with not close, the same level competition is fierce. But the network platform of the large span, informationization, low cost, multi-level and resource sharing, easy communication network pioneering characteristic is the root cause of the great heat. Higher school in considering entity venture platform at the same time, also need innovation, make full use of modern network technology advantages to carry out business network platform construction, enhances strong points and avoid weaknesses, complementary advantages, in order to achieve optimization university innovation talents training mode of purpose. [3]

\section{The significance and function about the construction of the platform of network pioneering}

According to the analysis of the status of colleges and universities should give full play to its own advantages, combining the characteristics of the network platform, can create outstanding professional research characteristics, and combining with the market the new network venture platform for college students to provide various business support. Construction of Internet and venture platform has the following the significance and role of: 
1: using the network venture platform advantage, to make full use of various resources universities to support the university student's pioneering work. Use of human resources in colleges and universities, research projects, research achievements on the advantages, and the university project team organization ability, and innovative thinking, professional complementary business development and support such as the uniqueness and set up a new university business education training mode and practice base. At the same time, the research and relying on the multiple network technology advantage, drawing a market advantages of third party platform, strengthen and large network venture platform, professional network technology platform, enterprise, institution, professional personnel's communication, provide more close to the market demand of training, trade, investment, consultation and so on various aspects of the help and services, gradually realize the normality of the business thinking of, so as to improve the success rate of business; Will the design results converted into productive forces, for university student's pioneering work from concept to provide practical production management research assessment of the overall support and service.

2: through this platform, provided a self development innovation, mutual communication, support mutually, mutual reciprocity and mutual benefit network space for college students. Will venture ability training and curriculum, and the combination of ascension of the university students' of entrepreneurship and innovation spirit, cultivate the spirit of innovation and independent thinking ability, team cooperation ability, improve overall quality, according to the actual situation of self as early as possible location, and know the market tendency, development and orientation for the future lay a practice base. Based on this, the formation of the daily operation of the market and professional management team and the full for university art design speciality various talents training services.

3: through the platform professional advantage and design show research results, make with art design professional feature unique network space. Will art design targeted, and cover range, close to people living demand, more easily to the business professional features a full play. From business to support business training, to really improve the students' autonomous learning enthusiasm, clear the direction of study. Through to the university student's pioneering work on the reasonable guide, according to the individual team advantage, build up the core competitive power. In strive to improve employment can also bring more innovation employment mode, the better the school-enterprise cooperation way, for students' learning and development offers multiple choice and chance.

4: create a practice drive research, to promote the practice teaching of the platform. Through the prompt understanding market trends and needs, the targeted professional curriculum. The actual combat training into the classroom, classroom knowledge will be used in practice. Research by practice to explore how to improve the teaching quality, reform the teaching mode, and will continue to various teaching achievements through the platform displayed, through the market for inspection. Realize the market and the talent cultivation and seamless connection between.

5: through the network business platform, enterprise, strengthen the school students and the connection between communication. Use the college each professional direction, all kinds of expertise of interaction between the classmate, independent form innovation team, set of all of optimization team work, for enterprise better services at the same time, form good teaching atmosphere and entrepreneurial environment of campus.

6: through this platform, and summarize the experience and lesson of entrepreneurs, sorting and study the characteristics of successful business, for daily teaching and new entrepreneurs to provide practice and theory on.

7: starting a business network platform in the continuous practice operation process, gradually full platform database, summarize the experience, improving the operation and management, perfect the venture platform function, attract more colleges and students participate in them, so as to form the stronger resource intensive advantages; Attract designers, enterprise and the independent brand into, enhance the market operation platform independent ability. Gradually enhance the teaching platform training function, at the basic teaching primarily university, on the basis of 
various resources through encourage social platform provides space for entrepreneurial, employment, professional knowledge training in the teaching training or guidance. [4] make venture platform not only have the business reference significance to study, more be a help to improve the teaching quality, improve college students' integrated qualities and ability of the network sharing space.

\section{The basic principles and methods about how to establishing a business network platform}

1. This platform to provide each other only choice, not engaged in cash transactions

The user classification: works, businessmen,, the network administrator; 2. How to Making a page

(1) Ordinary HTML page is suitable for, in the web page design can use DREAMWEAVER design software. Or choose the school most of the students are familiar with, also play the role of design practice.

(2) Home page to determine the style, can according to the school of the original page subject to design, also highlights the use function of change website, and then choose some fine works in the home page. Must be in the home page set on function, the users can see after landing site in the design works more relevant content.

2. Registration

(1) Registration of designer

The name, age, ID card, the user name, password (all need validation) fill out verification code, and then submit. To work of status register: can obtain the following functions, the work can upload their work, also can delete their works, still can change their work status, after landing also can see the work of others, but can't operate.

(2) Registration of business

Name, age, ID card, the user name, password (all need validation) and fill in the name of the company, set up a time, address, fill in verification code, and then submit. To merchants identity register: can obtain the function, can choose all the work, change can choose to work, the selected works, will be marked by the businessman has options, then can see after contact, if companies in three days not to work or to the site links, will be cancelled automatically state has chosen to let other merchants choice. (Works can also be choose cancel state)

\section{Database}

Picture database with oracle database handling Suggestions in large picture storage and delivery is very useful. Will the database classification, the school subject's professional classification, a few major points of a few. Upload press kind of storage after work. So convenient search, also facilitate maintenance. Works sent to the front page in add a watermark processing, this can prevent illegal things happen.

\section{Summary}

Through the network of research and construction business platform, using higher school plan as a whole the advantage of its resources, creating a platform of Internet and the theory research and practice, on the one hand, to adapt to the art design speciality of the university student's pioneering work request, for building the innovative country training high quality, creative ability, can the various positions in for entrepreneurial talent play its role; On the other hand, the study of Internet and venture platform in promoting college education teaching mode in the reform of the effect, make the talent training to keep pace with The Times, and the market closely, and give full play to the university and the main function of the higher education. This is also our university art design education keep up with higher education to reform the world needs. 


\section{References}

[1] Zhang YQ, Xu J. College students' business education research review [J].China power education, 2011, (16):36-38.

[2] Zhang M. College students' career consciousness research by university students in Zhejiang for example [J]. Herald of education, 2011, (05):117-119.

[3] $\mathrm{Hu}$ G L. College students to analyze the current situation and the countermeasures of starting a business network[J]. Modern education science, 2010, (3):114-121.

[4] Liu Y J. College students starting a business network problems and countermeasures study [J].The electronic commerce, 2011, (6):79-81. 